\title{
Growth rates of lava domes with respect to viscosity of magmas
}

\author{
Izumi Yokoyama \\ Higashi 1-17-7-1304, Kunitachi, Tokyo 186-0002 Japan
}

\begin{abstract}
In the discussion of lava dome formation, viscosity of magma plays an important role. Measurements of viscosity of magmas in field and laboratory are briefly summarized. The types of lava dome emplacements are classified into two, squeeze- and spine-type, by kinetic processes. The squeeze-type is the formation of a dome as a result of squeezes of magma through conduits and the latter is solidified magma forced to ascend by underlying fluid magma. An important parameter in the formation of such lava domes is their growth rates. Lava domes of squeeze-type are governed by the Hagen-Poiseuille Law which involves their viscosoties and other eruption parameters. At present, the real viscosity of magmas at the site of lava dome is still inaccessible. In order to avoid uncertainty in viscosity of magmas, a conception of «macroscopic viscosity» is proposed, which involves effects of chemical components, mainly $\mathrm{SiO}_{2}$ and volatile material, crystals and temperature, and their changes with time. Lava dome formations during the 20th century are briefly examined and their growth rates are estimated. The relationship between the growth rates and the $\mathrm{SiO}_{2}$ content of the magma is statistically studied, and the macroscopic viscosity is empirically expressed as a function of $\mathrm{SiO}_{2}$ content. The linearity between the two parameters is reasonably interpreted. This means that formation processes of lava domes are dominantly controlled by macroscopic viscosity of magma.
\end{abstract}

Key words lava domes - squeeze of magma growth rates of domes - Hagen-Poiseuille Law macroscopic viscosity

\section{Introduction}

Lava domes are one of the significant features of volcanism at the earth surface and their definitions and classifications have been published by several researchers. However, the processes of their formation have not always been systematically discussed. We know some examples of lava dome formations in historical times, which may give us fundamental knowledge on the movement of magmas in their formations.

Mailing address: Dr. Izumi Yokoyama, Higashi 1-177-1304, Kunitachi, Tokyo 186-0002 Japan; e-mail: iyokoya@aol.com
Yokoyama (2004) interpreted the formation processes of the 1909 Tarumai lava dome (andesite) and the 1944 Usu lava dome (dacite), both in Hokkaido, Japan, as being squeezed from magma forced to flow through the vents. Ascending magmas became lower in temperature, gas and water contents, with increased degrees of crystallization. Accordingly their rheologic behavior changed from Newtonian viscous flows to Bingham plastic flows. In fact, these lava domes assumed different features of effusions such as growth process, its rate and final configurations, due to differences in viscosities of their magmas and other eruption parameters.

The stationary magma flows in formation of lava domes are governed by the HagenPoiseuille Law which relates the flow rates to size of conduits, driving pressure gradient and viscosity of magmas. Considering that measurements of viscosity of juvenile magma in situ are difficult, we will utilize the growth rates of 
various lava domes to estimate effective viscosity of their magmas from the macroscopic and statistic viewpoint.

\section{Viscosity of magmas related to dome formation}

Knowledge on the physical properties of magma is fundamental to interpret the formation of lava domes. The mode of formation is influenced by viscosity of magma, which strongly depends on contents of $\mathrm{SiO}_{2}$, water, bubbles and microlites and temperature. Of these factors, only temperature is determinable at the dome sites under some circumstances. In the following, temperature and viscosity of magmas shall be discussed briefly in relation to dome formation.

\subsection{Temperature of magma}

Originally the temperature of magmas at reservoirs may be much higher than $1000^{\circ} \mathrm{C}$. Basaltic magma may keep its original temperature as far as vents due to its fluidity, while dacitic magma is viscous and moves slowly, and accordingly reaches vents at a lower temperature. Therefore, we may take the internal temperature of andestic and dacitic magmas during formation of lava domes to be lower than $1200^{\circ} \mathrm{C}$, around $1000^{\circ} \mathrm{C}$ on the average as a whole.

Field measurements of temperature of lavas are usually limited to those of basaltic lavas. For dacitic lavas, fumaroles on some dacitic domes are helpful. On the 1944 lava dome of Usu volcano, Hokkaido, whose formation was completed in 1945, there were a few strong fumaroles issuing gases which transmit the deep temperature. Some of them became accessible around 1946. The temperature of one of the strong fumaroles has been periodically measured by thermocouples. Its secular changes for 50 years (Yokoyama and Seino, 2000, fig. 13) indicate that the initial temperature of the fumarole was approximately $1000^{\circ} \mathrm{C}$. And accordingly, the original lava temperature should be higher than $1000^{\circ} \mathrm{C}$.
Huppert et al. (1982) suggested that the maximum temperature of the 1979 lava (basaltic andesite) of the Soufrière of St. Vincent was $800 \sim 1100^{\circ} \mathrm{C}$, by petrological studies. Murphy et al. (1998) applied the QUILF thermometer to the 1995-1997 Soufrière Hills andesite and obtained a range of temperature of $810 \sim 880^{\circ} \mathrm{C}$. Nakada et al. (1999) estimated temperatures of the 1990-1992 Unzen dacite lavas at $850 \sim 900^{\circ} \mathrm{C}$ with $\mathrm{Fe}-\mathrm{Ti}$ oxides in groundmass.

\subsection{Viscosity of magma}

In general, magmas at depths are higher than $1000^{\circ} \mathrm{C}$ in temperature, and may be viscous Newtonian fluids. As the magma ascends through conduits, its pressure lowers and its temperature drops gradually, and necessarily volatiles in the magma exsolve and crystallization progresses. Both the effects cause increases in magma viscosity.

When they cool further, their viscosities increase exponentially and plastic behavior is greatly enhanced; they behave as plastic Bingham flows. Considering that glaciers, of which ice has a viscosity of the order of $10^{13} \mathrm{~Pa} \cdot \mathrm{s}$ around $0^{\circ} \mathrm{C}$ (Paterson, 1994), flow slowly, we may assume even dacitic lavas (roughly $10^{7}$ $\mathrm{Pa} \cdot \mathrm{s}$ at $1000^{\circ} \mathrm{C}$ measured in laboratory by Goto, 1997) probably flow rather smoothly under endogenous or gravitational forces. In fact, Booth and Self (1973) measured viscosities of the 1971 basaltic lava of Etna volcano along its flows and obtained the viscosity range as $10^{3} \sim 10^{7} \mathrm{~Pa} \cdot \mathrm{s}$

Field measurements - The measurements have usually been made at vents or along lava flows and rarely at lava lakes of basaltic lavas which scarcely form lava domes. Their results are more natural than those of dry melts. Here, we may mention a unique example of field measurement of dacitic lava flow on Santiguito volcano; Rose (1973) calculated viscosity of the 1932-1933 lava flow near the vent as $5 \times 10^{7}$ $\mathrm{Pa} \cdot \mathrm{s}$, based on the equation of Nichols (1939). We have no information on the temperature of the lava flow, but it may have been a little lower than $1000^{\circ} \mathrm{C}$ because the site was near the vent. 
Huppert et al. (1982) theoretically estimated the viscosity of the dome lava of the 1979 eruption of Soufrière of St. Vincent as $2 \times 10^{11}$ $\mathrm{Pa} \cdot \mathrm{s}$ by observations of its lateral spreading. The lava dome was spread by different temperatures at each part, cooled skin, disrupted blocks and a flow front, and consequently the viscosity was determined to deviate from the simple model. Huppert et al. (1982) called it «effective viscosity».

Laboratory experiments - Since the 1930's, the viscosities of silicate rock-forming minerals and igneous rock melts at the temperature range higher than $1150^{\circ} \mathrm{C}$ have been measured in the laboratory. Goto (1997) studied the viscosities of silicate melts from some Japanese volcanoes, including the 1944 lava dome of Usu volcano and the 1992 one of Unzen volcano (table I). He applied the fiber-elongation method for a vis- cosity range higher than $10^{8} \mathrm{~Pa} \cdot \mathrm{s}$ (roughly temperature range lower than $950^{\circ} \mathrm{C}$ ) and counterbalanced sphere method for a viscosity range lower than $10^{5} \mathrm{~Pa} \cdot \mathrm{s}$ (roughly temperature range higher than $1150^{\circ} \mathrm{C}$ ). At present, the viscosity range $10^{5} \sim 10^{8} \mathrm{~Pa} \cdot \mathrm{s}$ is still left experimentally unsettled and only interpolation methods are applicable. In such viscosity ranges, magmas are half-solidified and usually common to the magmas forming lava domes. When we mention the viscosities of lavas in discussing dome formation in table I, they are reduced to the same temperature of $1000^{\circ} \mathrm{C}$ by interpolation. In this case, we refer to the experimental results obtained by Murase et al. (1985) and Goto (1997) that viscosities of melts of igneous rocks increase roughly $10^{1}$ times with temperature decrease of $100^{\circ} \mathrm{C}$ in a temperature range around $1000^{\circ} \mathrm{C}$.

Table I. Growth rates of the lava domes and viscosities of the lavas measured in laboratory.

\begin{tabular}{lccccc}
\hline \hline $\begin{array}{l}\text { Dome type, } \\
\text { volcano }\end{array}$ & $\begin{array}{c}\text { Lava type, } \\
\text { dome volume } \\
\left(\times 10^{7} \mathrm{~m}^{3}\right)\end{array}$ & $\begin{array}{c}\mathrm{SiO}_{2} \\
(\%)\end{array}$ & $\begin{array}{c}\text { Growth rate } \\
\log \left(\mathrm{m}^{3} / \text { day }\right)\end{array}$ & $\begin{array}{c}\text { Viscosity (a) } \\
\log \eta(\mathrm{Pa} \cdot \mathrm{s})\end{array}$ & $\begin{array}{c}\text { Reference } \\
\text { (Viscosity meas. })\end{array}$ \\
\hline
\end{tabular}

\begin{tabular}{|c|c|c|c|c|c|c|}
\hline \multicolumn{7}{|l|}{ Squeeze-type } \\
\hline Soufrière S.V. (1979) & BA & 3.5 & 55 & 5.73 & \multirow[t]{5}{*}{$7.3(b), 11.3(c)$} & \multirow[t]{5}{*}{ Huppert et al. (1982) } \\
\hline Colima (1998) & $\mathrm{A}$ & 0.04 & 59 & 5.58 & & \\
\hline Lamington (1951) & A & 6 & 59 & $6.20(5.7)(6.3)$ & & \\
\hline Redoubt (1989) & A & 2 & 60 & 6.34 & & \\
\hline Soufrière Hills (1996) & A & 6.8 & 60 & 5.30 & & \\
\hline Tarumai (1909) & A & 1.5 & 60 & $6.58(7.0)$ & \multirow[t]{4}{*}{6} & \multirow[t]{5}{*}{ Kani and Hosokawa (1936) } \\
\hline Bezymianny (1956) & A & 4.2 & 60 & $\mathbf{6 . 1 5}(4.6)(5.2)$ & & \\
\hline Shiveluch (1980) & A & 1 & 61 & $5.27(5.4)$ & & \\
\hline Pelée (1902) & A & 3.7 & 62 & $\mathbf{5 . 5 0}$ & & \\
\hline Mt. St. Helens (1980) & $\mathrm{D}$ & 1.0 & 63 & $5.92(4.6)(4.6)$ & $c a .6$ & \\
\hline Santiaguito (1922) & $\mathrm{D}$ & 20 & 64 & $5.20(4.9)(4.6)$ & $7.7(\mathrm{c})$ & Rose (1973) \\
\hline Popocatépetl (1996) & A & 1.1 & 64 & 5.26 & & \\
\hline Unzen (1992) & $\mathrm{D}$ & 5 & 66 & 5.70 & 6.0 & Goto (1997) \\
\hline Usu (1944) & D & 4.4 & 69 & $5.05 \quad(5)$ & 6.8 & Goto (1997) \\
\hline Novarupta (1912) & $\mathrm{D}$ & 0.5 & 73 & $4.40 \quad(6)$ & & \\
\hline \multicolumn{7}{|l|}{ Spine-type } \\
\hline Lamington (1951) & A & 0.07 & 60 & 4.82 & & \\
\hline Pelée (1902) & A & 0.003 & 62 & 4.45 & & \\
\hline
\end{tabular}

A - Andesite; D - Dacite; BA - Basaltic Andesite; (a) - reduced to $1000^{\circ} \mathrm{C}$; (b) - deduced from petrology (Huppert et al., 1982); (c) - field data (temperature probably $\left.1000^{\circ} \mathrm{C}\right)$; (d) - after Newhall and Melson (1983); (e) after Swanson et al. (1987), for long-term formation. 
Furthermore, viscosities of natural magmas are controlled by water, bubble and crystal contents which are not always easily determinable in situ. Recently viscosities of several volcanic rocks for a dissolved water content ranging from dry to 3 or $4 \%$ for wide temperature ranges were studied by Romano et al. (2003), Giordano and Dingwell (2003) and Giordano et al. (2004); hydrations remarkably lower the viscosities of dry melts. Sparks (1997) discussed large increases in magma viscosity resulting from degassing and microlite growth as causes of pressurisation in lava dome eruptions.

It is not easy for us to measure the properties of actual magmas in situ such as viscosity, water and crystal contents, and laboratory measurements of rock viscosities remain approximate for a certain viscosity range. In order to avoid uncertainty about the viscosities of ascending magma, I later propose a conception of «macroscopic viscosity».

\section{Classification of lava domes and modes of their formations}

\subsection{Classification of lava domes}

Lava domes have been defined in various ways. For example, Bardintzeff and McBirney (1998) define six principal types of domes based mainly on their morphological aspects: a) cryctodomes, b) plug domes, c) Peléan domes, d) spines, e) lava domes and f) Coulées. The present paper does not always adhere to such definitions. Cryptodomes are theoretically possible, but I do not know of any examples geophysically verified. In fact, as discussed by Yokoyama (2004), during the 1944 lava dome formation of Usu volcano, a $65 \mathrm{~m}$ high mound was caused by magma intrusion through a conduit, but the magma top remained at a depth of $100 \mathrm{~m}$. It is not always necessary to assume magma intrusion directly beneath the mounds. Peléan domes are defined as collapsed parts of plug domes. Some lava domes are formed by the spread of relatively fluid lava over squeezed domes. From the standpoint of formation mechanism, plug domes and spines should be different from the others; they extrude through vents in an almost solidified state, even if the inner part remains soft.

The possibility of formation of a lava dome and its morphology change with the viscosity of magmas. Lava domes are highly possible with dacitic compositions and rare with basaltic compositions in the order of silica contents.

\subsection{Types of lava dome formation}

The substantial mode of lava dome formation is squeezing, or forced extrusion, of magma through a narrow opening similar to toothpaste. Such a behavior is a characteristic of the Bingham fluids. This mode shows a wide variation, such as the above-mentioned six types defined by final morphology. From the standpoint of magma movements at vents, we may classify two types: squeeze of fluidal or half-solidified magma (squeeze-type), and extrusion of solidified magma (spine-type). These two also include a variation according to the viscosity of magma, endogenous pressure, size of vents and degrees of magma solidification.

Squeeze-type - Usually magmas at high temperature are fluidal. As the magma ascends through a conduit as a viscous flow, it half solidifies due to lowering in temperature and pressure. The boundary viscosity between liquid and solid is approximately $10^{13} \mathrm{~Pa} \cdot \mathrm{s}$ (e.g., Huppert, 1982). Half-solidified magma behaves like a plastic Bingham body and piles up at the vent; this is a lava dome of squeeze-type. We assume magma movements of this type exactly or approximately obey Hagen-Poiseuille Law.

Spine-type - When magma lifts through a conduit, sometimes it solidifies totally or partly en route beneath the vent and extrudes as a solid spine, the interior of which may remain soft. Extrusions of solidified lava or lava spines are not similar to squeezes of fluidal or half-solidified lavas but are displacements of solid lava bodies overcoming friction of the ground around conduits. The solid lavas are driven up by fluid magma beneath, whose viscosity effects their displacements. As will be seen later, their growth rates are far smaller than the squeeze-type because of larger resistance between solidified spines and conduit walls. 
Rare examples of the spine-type in the 20th century were found in the 1902-1903 eruption of Mt. Pelée and in the 1951 eruption of Lamington volcano. Both the spines may have been fluid flows at the early stage, and changed to plug flows, in which the central part had a uniform speed, before becoming solidified at the top part.

In some cases, during formation of domes of squeeze-type, spinescent extrusives have appeared at the surface - the 1944 Usu dome (Yokoyama, 2004) and the 1996 Soufrière Hills dome (Watts et al., 2002), for example. Such apparent spines may be lava blocks solidified at or near the surface, and deeper parts must remain fluidal.

\subsection{Alternation of formation and destruction of lava domes}

The history of volcanic eruptions shows that dome formation and demolition have alternated, often being repeated several times. Shiveluch volcano, Kamchatska has finished five cycles of production and demolition since the 19th century and the last formed in 1980 (Dvigalo, 1988). In the case of Tarumai volcano, Hokkaido, the 1874 eruption destroyed the pre-existing lava dome (I), and the next eruption in 1909 produced the new lava dome (II) at the site of the previous lava dome (I) (Oinouye, 1909). In the following examples, the last eruptions demolished the preexisting lava domes, and another production may be expected in the future.

The 1982 eruption of El Chichon volcano, Chiapas - No historical eruptions of El Chichon volcano were known before 1982. According to Duffield et al. (1984), growth of a lava dome following excavation of a crater had occurred at least twice in the past. Before the 1982 eruption, there were two internal nested domes within the summit oval crater measuring $1900 \times 900 \mathrm{~m}$. The larger central dome was conical with a maximum relative height of approximately $200 \mathrm{~m}$, and the other is the smaller flank dome. The 1982 eruption destroyed the central dome and caused pyroclastic flows at the last phase, leaving the 1982 crater which is approximately $1 \mathrm{~km}$ diameter and approximately 240 m depth (Macias et al., 1997).
The 1982 eruption of Galunggung volcano, Java - In the history of this volcano, the 1833 eruption produced lava dome (I) which was destroyed by the 1894 eruption, and the 1918 eruption produced lava dome (II) named Mt. Jadi, measuring $560 \times 440 \times 85 \mathrm{~m}$ on the crater lake. On April 5, 1982, a new activity took place and the pre-existing lava dome (II) was destroyed within one month. The activity stopped in January 1983 leaving a cinder cone on the crater floor (Katili and Sudradjat, 1984).

\subsection{Examples of lava dome formations}

In the following, each type of dome formations will be exemplified by the domes formed in the 20th century to estimate their growth rates. Later we apply the Hagen-Poiseuille Law to the dome formation under constraint that the dome is driven by liquid.

\subsubsection{Lava domes of squeeze-type}

A few papers have compared growth rates of several lava domes. Newhall and Melson (1983) reviewed the dome growth of more than 70 volcanoes in historical times, and related it to their explosive activity. Among their data, duration of dome growth ranges from 0.3 to 2600 weeks. One of their conclusions is that the average rate of dome growth shows no systematic relationship to the timing or character of explosions.

Swanson et al. (1987) discussed the volumetric growth of a composite dome during $1980 \sim 1983$ on Mt. St. Helens. Nine dominantly nonexplosive episodes of dome growth after 1981 were separately described. Furthermore, they compared the growth of four relatively long-lived contemporary lava domes at Mt. St. Helens for 1980 1983 (3.2 years), Lamington for 1951 1952 (1.4 years), Bezymianny 1956 1982 (27.3 years) and Santiaguito 1922 1982 (61.5 years). They remark that the dome, its feeding conduit and its magma reservoir are in a delicate balance, able to alternate over short periods of time between dominantly explosive and effusive activity. 
During dome formations, magma movements fluctuate sometimes repeating the rise and fall in growth of lava domes. This may be attributed to changes in the driving pressure of magma from the standpoint of the HagenPoiseuille Law. On the other hand, Melnik and Sparks (1999) interpreted large changes in the dome extrusion rate and pulsatory patterns of dome growth observed during the 1995-1999 eruption of the Soufrière Hills, Montserrat by the nonlinear effects of crystallization and degassing in the ascending magma.

As far as we assume Hagen-Poiseuille Law for magma flows in the formation of lava domes of squeeze-type, the following conditions are necessary in collecting the data. The flows must be stationary for a certain period, possibly a few weeks, and explosions and collapses of the dome have not intervened in the period. To assume stationary magma flows, it is desirable to select larger domes, such as larger than $10^{7} \mathrm{~m}^{3}$, more or less in the final volume because smaller domes can be formed even by unstable processes.

The following examples proved not to satisfy the above conditions because their volumes are not sufficiently large.

The 1989 dome of Lascar volcano, Northern Chile - (The dome volume was roughly $10^{6}$ $\mathrm{m}^{3}$ after Matthews et al., 1997), the 1990-1992 dome of Galeras volcano, Colombia $\left(4 \times 10^{5} \mathrm{~m}^{3}\right.$ after Calvache and Williams, 1997), the 1991 dome of Mount Pinatubo, Philippines $\left(3 \sim 6 \times 10^{5}\right.$ $\mathrm{m}^{3}$ after Daag et al., 1996) and the 1992 dome of Merapi volcano, Java $\left(2 \times 10^{6} \mathrm{~m}^{3}\right.$ after Subandriyo et al., 1992).

In the following, lava dome formations for which quantitative data exist to estimate growth rates will be reviewed. The examples shall be mentioned in order of the sequence of eruptions, and growth rates are expressed in $\mathrm{m}^{3} /$ day for practice in field observations, not in the SI system, and accompanied with the error ranges, not probable errors.

The 1902 dome of Mt. Pelée, Martinique According to Lacroix (1904), the 1902 dome formed at the summit during the period from May to October 1902. The beginning of dome formation may be assumed as the day of the catastrophe, May 8, and the dome may be as- sumed to have been completed on October 4, when a new spine began to extrude above the dome. The duration of dome formation is roughly 150 days and its volume as of October 4 is estimated in the sketches given by Lacroix (1904, fig. 28) as $3.7 \times 10^{7} \mathrm{~m}^{3}$, on the assumption that the dome is a circular cone. Then, the growth rate is

$$
Q=3.7 \times 10^{7} \mathrm{~m}^{3} / 120 \text { days }=3.1 \times 10^{5} \mathrm{~m}^{3} / \text { day } .
$$

The error range in this estimate is derived from the errors in estimation of volume of the dome; it can be erroneous $\pm 10 \%$.

Both the magmas of the 1902 dome and the 1902 spine of Mt. Pelée were andesite, but they manifested a large difference in their formation processes because the former was a squeeze flow and the latter was solidified at some depth beneath the vent before extrusion. The $\mathrm{SiO}_{2}$ content of the lava dome is $62 \%$ (Lacroix, 1904, p. 573).

The 1909 dome of Tarumai volcano, Okkaido - The formation of this lava dome is discussed in detail by Yokoyama (2004). The lava dome formed in the summit crater in 4 days in April 1909. The andesite magma was squeezed through the vent of $30 \mathrm{~m}$ diameter in a half-solidified state.

$$
Q=1.5 \times 10^{7} \mathrm{~m}^{3} / 4 \text { days }=3.8 \times 10^{6} \mathrm{~m}^{3} / \text { day } .
$$

The error range in this estimate is derived from the errors in estimation of duration and volume of the dome; the duration is $4 \pm 2$ days and the volume can be erroneous at $\pm 10 \%$.

Kani and Hosokawa (1936) measured the viscosity of the dry melt from the Tarumai lava dome, and the results are extrapolated to approximately $10^{6} \mathrm{~Pa} \cdot \mathrm{s}$ at a temperature of $1000^{\circ} \mathrm{C}$. The Reynolds number of the lava flow in the conduit during the formation of the Tarumai dome was very small $\left(2.2 \times 10^{-3}\right)$ and hence the flow was laminar (Yokoyama, 2004). The $\mathrm{SiO}_{2}$ content of the dome lava is $60 \%$.

The 1912 dome of Novarupta dome, Katmai, Alaska - The 1912 eruption in the Valley of Ten Thousand Smokes was discussed in detail by Hildreth (1983) and Fierstein et al. (1997). In June 1912, magma of approximately 
$15 \mathrm{~km}^{3}$ erupted from the Novarupta caldera, and quasi simultaneously, at Mt. Katmai, $10 \mathrm{~km}$ $\mathrm{E}$ of Novarupta, a $600 \mathrm{~m}$ deep caldera formed. The Novarupta dome is blocky and a circular knoll of $380 \mathrm{~m}$ diameter and $65 \mathrm{~m}$ high is centered within the $2 \mathrm{~km}$ diameter basin of subsidence that was the source of the 1912 ejecta. It apparently reached the final level of formation at the end of the eruptive sequence, possibly in several months after the last major pumice eruption. Its volume is approximately $5 \times 10^{6} \mathrm{~m}^{3}$ which barely satisfies the condition upon the minimum volume of lava domes. If we take «several months» as 200 days, the growth rate is

$$
Q=2.5 \times 10^{4} \mathrm{~m}^{3} / \text { day. }
$$

The error range in this estimate is derived from the errors in estimation of duration and volume of the dome; duration is $200 \pm 50$ days and the volume can be erroneous at $\pm 10 \%$.

The $\mathrm{SiO}_{2}$ content of this lava dome ranges $65 \sim 77 \%$, and is $73 \%$ on the average (Hildreth, 1983).

The 1922-1925 Santiaguito dome, Guatemala - According to Rose (1972, 1973), Santa Maria volcano erupted in 1902 for the first time in history, producing pyroclastics of $5.5 \mathrm{~km}^{3}$ and a large and deep crater was formed on its SW slope. In June 1922, a lava dome (Santiaguito) rose in the 1902 crater and grew to a relative height of $400 \mathrm{~m}$ by the end of 1923 .

Rose (1973, figs. 1 and 7) showed a diagram of the estimate of the magma extrusion rate during the historic activities of the volcano. The highest rate for the period 1922 1925 is given in annual rate as

$$
Q=60 \times 10^{6} \mathrm{~m}^{3} / \mathrm{yr}=1.6 \times 10^{5} \mathrm{~m}^{3} / \mathrm{day} .
$$

The error range in this estimate can be $\pm 20 \%$ of the value if we consider ambiguity in the original diagram.

Rose (1973) calculated the viscosity of the 1932-1933 lava flow of Santiaguito near the vent as $5 \times 10^{7} \mathrm{~Pa} \cdot \mathrm{s}$, as mentioned previously. The $\mathrm{SiO}_{2}$ content of the 1967 dome rock is $64 \%$ (Stoiber and Rose, 1969).

The 1944 lava dome of Usu volcano, Hokkaido - The formation of this lava dome was ful- ly discussed in the previous paper (Yokoyama, 2004). This dome is unique in that it was formed at the base of a volcano, flat ground, not within a crater. This is a variation of squeeze-type. The upward movement of magma was slow and the uppermost part was solidified in the course of upheaval while the deeper part remained partly solidified and movable. The top part was successively followed by emergence of solidified slablike lavas, forming an onion structure. The volume of the dome including the subsurface part was estimated at $4.4 \times 10^{7} \mathrm{~m}^{3}$ by Yokoyama (2004). The dome grew up rather uniformly for the early 13 months while the activity continued for approximately 17 months in a combined total. Hence, the typical growth rate of the dome is obtained as

$$
Q=4.4 \times 10^{7} \mathrm{~m}^{3} / 13 \text { months }=1.1 \times 10^{5} \mathrm{~m}^{3} / \text { day } .
$$

The error range in this estimate is derived from the errors in estimation of subsurface volume of the dome; it can be erroneous at $-25 \%$.

As mentioned above, Goto (1997) measured the viscosity of dry melts from the lava dome as $10^{6.8} \mathrm{~Pa} \cdot \mathrm{s}$ at a temperature of $1000^{\circ} \mathrm{C}$. The magma is dacite of $\mathrm{SiO}_{2}$ content $69 \%$.

The 1951 dome of Mt. Lamington, Papua Our knowledge on the 1951 eruption of Lamington volcano entirely depends on the paper of Taylor (1958). A gigantic eruption occurred at the summit of the volcano on January 21, 1951. A lava dome began to extrude on January 25 and the first phase ended on March 5 when it reached a height of $450 \mathrm{~m}$ and the paroxysmal explosion shattered the dome causing pyroclastic flows.

The growth curve of the dome in height is given by Taylor (1958, fig. 154) and the maximum rate is $30 \mathrm{~m} /$ day between February 3 and 9. He states that this rate is probably the highest recorded for the dome uplift. In the present paper, growth rates are defined as increases in volume of domes. Then, the growth rate is calculated for the period from January 25 to March 5 under the assumption that the dome was a cone with $730 \mathrm{~m}$ basal diameter (Taylor, 1958, fig. 4) and $450 \mathrm{~m}$ height. Then we have

$$
Q=\pi / 4 \cdot 730^{2} \times 450 / 3 / 40 \text { days }=1.6 \times 10^{6} \mathrm{~m}^{3} / \text { day } .
$$


The error range in this estimate is derived from the error in estimation of volume of the dome; it can be $+20 \%$.

It is noticeable that a knife-edged spine emerged from the center of the dome on August 19, similarly to that at Mt. Pelée in 1902. This spine will be referred to later. The $\mathrm{SiO}_{2}$ content of the lava dome is 59\% (after Taylor, 1958).

The 1956 dome of Bezymianny volcano, Kamchatka - According to Gorshkov (1959), the first historical eruption of Bezymianny volcano began on October 22, 1955 after threeweeks' earthquake swarm. The activity had developed into the paroxysmal explosion on March 30, 1956 and the new crater had the shape of a semi-ring of $1.5 \mathrm{~km}$ by $2 \mathrm{~km}$ in size. Following the explosion of March 30, which produced large pyroclastic flows, an extrusive dome grew in the new crater. By early July, after one month, the dome was mostly completed, approximately $320 \mathrm{~m}$ high above the crater floor and $340 \mathrm{~m}$ in average diameter. Its volume, the sum of the two trapezoids, is estimated at $4.2 \times 10^{7} \mathrm{~m}^{3}$. The growth rate of the dome is

$$
Q=4.2 \times 10^{7} \mathrm{~m}^{3} / 30 \text { days }=1.4 \times 10^{6} \mathrm{~m}^{3} / \text { day } .
$$

The error range in this estimate is derived from the errors in estimation of duration and volume of the dome; the duration can be 40 days and the volume can be erroneous at $\pm 10 \%$.

The activity continued till March 1957, and was repeated during March 1965 to March 1970 accompanying pyroclastic flows, and later numerous explosive episodes took place with lava extrusion. The lava of the 1956 dome is andesite and 59.9 in $\mathrm{SiO}_{2}$ percentage (Gorshkov, 1959).

The 1979 dome of the Soufrière of St. Vincent, West Indies - The 1979 eruption of Soufrière volcano was first discussed by Shepherd et al. (1979). The eruption began on April 13 and a series of strong explosions continued until April 26. The extrusion of lava was observed from about May 6 until its final emplacement after 5 months. Huppert et al. (1982) applied a theoretical analysis to the radial spreading of the lava extrusion accumulated in the crater, and estimated the «effective» viscosity at $2 \times 10^{11} \mathrm{~Pa} \cdot \mathrm{s}$.
On the other hand, the 1909 Tarumai dome did not deform noticeably after the emplacement (Yokoyama, 2004) though its formation was not observed quantitatively. It is probably because the Tarumai lava is andesite and was plastic after the squeeze. Huppert et al. (1982) also estimated the viscosity at $2.1 \times 10^{7} \mathrm{~Pa} \cdot \mathrm{s}$ at $1000^{\circ} \mathrm{C}$ from the petrological model assuming a phenocryst content of $45 \%$ and dacitic liquid phase.

Huppert et al. (1982, table II and fig. 11) published the growth data of the Soufrière dome during the period May to October 1979 when the growth rate had gradually decreased. They interpreted that the lava ascended under a decreasing hydrostatic driving pressure. The growth rate at the early stage for 65 days (May 7 July 10) is obtained as

$$
Q=3.5 \times 10^{7} \mathrm{~m}^{3} / 65 \text { days }=5.4 \times 10^{5} \mathrm{~m}^{3} / \text { day } .
$$

In table II of Huppert et al. (1982), the highest rate is $6.3 \times 10^{5} \mathrm{~m}^{3} /$ day for 19 days (May 7 to 25); the error range in the above estimate can be indicated by this value. The $\mathrm{SiO}_{2}$ content of the 1979 lava is $55.0 \%$ (basaltic andesite, Huppert et al., 1982).

The 1980 domes of Mt. St. Helens, Washington - The great eruption of Mt. St. Helens on May 18, 1980 was followed by formation and collapse of lava domes in the newly formed crater $1.5 \times 3 \mathrm{~km}$ across. Moore and Albee (1981) presume the bulge at the summit just before the outburst as a cryptodome of $0.11 \mathrm{~km}^{3}$ in volume directly beneath the summit. I already remarked that such a bulge could be formed by upward thrust of ascending magma.

Swanson et al. (1987, table 2 ) obtained the average growth rate as $0.014 \mathrm{~km}^{3} / \mathrm{yr}\left(3.8 \times 10^{4}\right.$ $\mathrm{m}^{3} /$ day) for the period of 1981 1983. During the period, lavas extruded step by step and a composite dome continued to grow. The present paper selects the relatively short-lived magma extrusions, 4 steps in 1980 and 5 steps in 1981 (Swanson et al., 1987, table 1). These domes were partly destroyed by subsequent explosions one after another. The average growth rate of the 9 steps for 34 days is obtained as

$$
Q=28.5 \times 10^{6} \mathrm{~m}^{3} / 34 \text { days }=8.4 \times 10^{5} \mathrm{~m}^{3} / \text { day } .
$$


On the other hand, Moore et al. (1981, table 58) compared dimensions, volume, growth periods etc. of three domes in June, August and October 1981. The mean growth rate of the three domes is estimated as $9.6 \times 10^{5} \mathrm{~m}^{3} /$ day. This estimate indicates the error range.

Murase et al. (1985) measured viscosity of the dome lava (melt) in the laboratory. The viscosity reduced to $1000^{\circ} \mathrm{C}$ is approximately $10^{6}$ $\mathrm{Pa} \cdot \mathrm{s}$. The $\mathrm{SiO}_{2}$ content of the dome materials on Mt. St. Helens ranges from 61 to $64 \%$ (after Swanson et al., 1987).

The 1980 lava dome of Shiveluch volcano, Kamchatka - The volcano has produced lava domes 5 times in the explosion crater since the 19th century. During the 1980-1981 eruption, a new lava dome of approximately $150 \mathrm{~m}$ height formed. Dvigalo (1988) observed the growth of the dome with a photogrammetric method for the period from July 1980 to March 1982. The growth rate was the maximum for the first survey period (July to October 1980) amounting to

$$
Q=1.86 \times 10^{5} \mathrm{~m}^{3} / \text { day. }
$$

In this estimate, the volume can be erroneous at $\pm 10 \%$. The $\mathrm{SiO}_{2}$ content of the lava dome is $61 \%$.

The 1989-1990 lava dome of Redoubt volcano, Alaska - During six months of the 19891990 eruption, the volcano repeated a domegrowth and -destructive phase in which 14 shortlived andesite domes were formed and 13 subsequently destroyed. Miller (1994) estimates the cumulative volume of the domes dividing the period of six months into three segments, I, II and III, and calculates the growth rate of each segment: segment I produced the largest dome with the highest growth rate. The lava domes in segments II and III were not sufficiently large in volume to show stable growth rates. The growth rate in segment I is given by Miller (1994, table 3) as

$$
Q=20 \times 10^{6} \mathrm{~m}^{3} / 9 \text { days }=2.2 \times 10^{6} \mathrm{~m}^{3} / \text { day } .
$$

The volume of the dome is erroneous at $\pm 5 \times 10^{6}$ $\mathrm{m}^{3}$. The $\mathrm{SiO}_{2}$ content of the dome lava is $59.8 \%$ on the average (Miller, 1994, table 2).

The 1990-1992 lava domes of Unzen volcano, Kyushu - Unzen volcano reawoke at the summit crater in November 1990 after 198 years' quiescence. On May 20, 1991, magma extruded in the summit crater, forming lobes and domes which flowed very gently and showed elongated forms. Thereafter, magma was continuously supplied to form successive domes. Seven lava domes were formed at the summit during May 1991 to April 1992. New domes pushed and partly overrode the preexisting domes to form an onion structure that resulted from squeeze processes, similar to the 1944 lava dome of Usu volcano (Yokoyama, 2004): the Unzen lava domes belong to the squeeze-type of half-solidified magma. Afterwards the domes repeatedly collapsed to form pyroclastic flows along the slope.

According to Nakada (1996), the magma effusion rate was highest in September 1991 amounting to

$$
Q=(4 \sim 6) \times 10^{5} \mathrm{~m}^{3} / \text { day. }
$$

Thereafter it decreased with time before stopping in 1995. The error range in the above estimate is ambiguity of growth periods.

Goto (1997) measured the viscosity of dry melts of the 1992 Unzen lava dome as $10^{6.0} \mathrm{~Pa} \cdot \mathrm{s}$ at $1000^{\circ} \mathrm{C}$. The $\mathrm{SiO}_{2}$ content of the dome lava is $66 \%$ on an average (after Yanagi et al., 1992).

The 1995-1997 lava domes of Soufrière Hills volcano, Montserrat - Phreatic explosions began in July 1995 at this volcano, and were followed by a continuous eruption of andestic magma in the form of a lava dome in November 1955. The eruptions have been monitored and discussed from various standpoints. The growth patterns of the lava dome during the period of November 1995 to December 1997 are illustrated and the growth rate are graphically reported: Sparks et al. (1998, fig. 2) present the extrusion rates as a function of time and Watts et al. (2002, fig. 3) present the change in dome volume. We search the periods of monotonous growth to estimate growth rates of the lava dome. Considering the change in dome height given by Melnik and Sparks (2002, fig. 1), we select two periods from February 17 to September 30, 1996 (Stage III), and October 1, 1996 to May 13, 1997 (Stages IV and V). The latter period is selected on the condition that the higher 
growth rate is preferable. The growth rate through Stages IV and V is graphically determined in the diagram of change in dome volume given by Watts et al. (2002, fig. 3b)

$$
Q=68 \times 10^{6} \mathrm{~m}^{3} / 340 \text { days }=2.0 \times 10^{5} \mathrm{~m}^{3} / \text { day } .
$$

Naturally this roughly agrees with the values given by Sparks et al. (1998, fig. 2) and the error range is given by the growth rate in Stage III. The $\mathrm{SiO}_{2}$ content of the dome lava is $59.5 \%$ on an average (Murphy et al., 1998).

The 1996 lava dome of Popocatépetl volcano, Central México - The summit of Popocatépetl volcano is $5450 \mathrm{~m}$ a.s.l. and located approximately $50 \mathrm{~km}$ distant from México City. Popocatépetl had repeated small explosive eruptions in 1920-1922 and produced a small lava plug in the summit crater, but no lava flows. The present activity began in 1994. After the first outburst on December 24, 1994, lava domes formed several times in the elliptical summit crater, which measures $600 \mathrm{~m}$ by 400 $\mathrm{m}$, and is approximately $330 \mathrm{~m}$ deep, measured from the lower crater rim.

According to Global Volcanism Network (1996) and S. De la Cruz-Reyna (personal communication), dome $\mathrm{A}$ in the summit crater was found first on March 25, 1996 from the air and had grown to $1.1 \times 10^{7} \mathrm{~m}^{3}$ by May 25 when the growing stopped. Then the growth rate is

$$
Q=1.1 \times 10^{7} \mathrm{~m}^{3} / 61 \text { days }=1.8 \times 10^{5} \mathrm{~m}^{3} / \text { day } .
$$

The error range in this estimate is derived from the errors in estimation of volume of the dome; it may be erroneous at $\pm 10 \%$.

The bulk of dome A had been demolished by repeated explosions by August 1996. The $\mathrm{SiO}_{2}$ content of the lava is 64\% (Robin and Boudal, 1987).

The 1998 lava dome of Colima volcano, Western México - Colima volcano $(3850 \mathrm{~m}$ a.s.1.) has experienced at least 50 eruptions since 1560. The 1913 summit eruption produced disastrous pyroclastic flows. After that, lava rose through the vent, and block lavas gradually filled the $200-\mathrm{m}$-wide summit crater by 1957 . The latest series of eruptions began in March 1991, and lavas extruded onto the sum- mit crater resulted in block flows and ash flows on the south flank of the volcano.

Navarro-Ochoa (2002) reports on the emplacement of the November 1998-February 1999 lava flows. On November 20, 1998, a lava dome grew rapidly at a rate of $4.4 \mathrm{~m}^{3} / \mathrm{s}$ inside the summit crater and its volume amounted to $3.8 \times 10^{5} \mathrm{~m}^{3}$ in $24 \mathrm{~h}$. On the following day, the lava dome began to collapse, causing the largest pyroclastic flows on November 25-26, and thereafter, block-lava flows went down in three branches. Their volume is estimated at approximately $3.9 \times 10^{7} \mathrm{~m}^{3}$. In this case, the dome is small in volume but may be assumed to have been formed by Hagen-Poiseuille Law because its growth rate is rather high and it was shortly followed by a large amount of lava flows. We take the growth rate as

$$
Q=3.8 \times 10^{5} \mathrm{~m}^{3} / \text { day } .
$$

The error range in this estimate is derived from the errors in estimation of duration and volume of the dome; both of them can be erroneous at $\pm 10 \%$. The $\mathrm{SiO}_{2}$ content of the lava is $59 \%(\mathrm{Na}-$ varro-Ochoa, 2002).

\subsubsection{Lava domes of spine-type}

There are only two examples of this type that have been monitored quantitatively, as far as the present author knows. One is the 1912 lava spine of Mt. Pelée, and the other is the 1951 lava spine of Lamington volcano. They were solidified lavas driven by underlying magmas through conduits, and met with resistance at the conduit walls. Hence, their growth rates do not obey Hagen-Poiseuille Law.

The 1902 lava spine of Mt. Pelée - This lava dome is characterized as an extrusion of a huge solidified spine. A lava dome formed at the summit of Mt. Pelée from May to October 1902. During this period, on May 8, pyroclastic flows occurred, devastating the town of St. Pierre along the sea. According to Lacroix (1904), a spine extruded above the top of the dome after the dome was completed. The extrusion of the spine first began on the night of November 3-4, 1902. It may have ascended 
through the vent of the preceding lava dome. The 1902 1903 lava spine of Mt. Pelée measured $190 \mathrm{~m}$ high above the terrace in March 1903 and approximately $60 \mathrm{~m}$ across at its base; some parts were partially hollow. It is different from the 1944 lava dome of Usu, which grew laterally after the lava reached the surface and completed an onion structure. The spine repeated noticeable growths 3 times, and small collapses with short steps, during the period from November 1902 to September 1903, as illustrated and sketched by Lacroix (1904, figs. $29 \sim 35)$. The total amount of extrusion is estimated at approximately $620 \mathrm{~m}$.

Lacroix (1904) reported that the maximum growth rate of the spine was $10 \mathrm{~m} /$ day for November 3 4. If we assume the section of the spine as a 60 m-diameter-circle (Lacroix, 1904, fig. 55), the rate of magma flow to cause the rise of the spine is approximately

$$
Q=\pi / 4 \cdot 60^{2} \times 10 \mathrm{~m}^{3} / \text { day }=2.8 \times 10^{4} \mathrm{~m}^{3} / \text { day } .
$$

The error range in this estimate is derived from the errors in estimation of sectional diameter and ascending velocity of the spine; both of them may be erroneous at $\pm 10 \%$.

The upward movement of the solidified spine through the conduit may have met with more friction than fluidal flows. The lava is andesite with $\mathrm{SiO}_{2}$ content of $62 \%$ (Lacroix, 1904).

The 1951 lava spine of Lamington volcano The 1951 eruption of Lamington volcano was accompanied by extrusion of a spine. A lava dome began to extrude after the gigantic eruption in March 1951. When the dome reached a height of approximately $450 \mathrm{~m}$ in March, it was partly destroyed. In July a lava spine began to extrude at the center of the dome. Its growth curve is given by Taylor (1958, fig. 4). The uplift rate of the spine is estimated at $83 \mathrm{~m} / 10$ days by the growth curve, and the spine is assumed to be a cone with roughly $175 \mathrm{~m}$ basal diameter (Taylor, 1958, fig. 140) and $83 \mathrm{~m}$ height. Then we have

$Q=\pi / 4 \cdot 175^{2} \times 83 \times 1 / 3 \mathrm{~m}^{3} / 10$ days $=$ $=6.6 \times 10^{4} \mathrm{~m}^{3} /$ day.

The error range in this estimate is derived from the errors in estimation of sectional diameter of the spine, and it may be erroneous at $\pm 10 \%$.

According to Taylor (1958), this monolith showed neither plastic deformation nor slickensides. The $\mathrm{SiO}_{2}$ content of the spine is $60 \%$ (after Taylor, 1958).

\section{Growth rate of lava domes of the squeeze- type and macroscopic viscosity}

We select the 15 lava domes of the squeezetype formed in the 20th century with reliable observational data, and we can discuss their growth rates statistically.

Lava flows may be modeled as viscous or plastic fluids. Flows of dome-forming lava are usually laminar, as confirmed by the 1909 lava dome of Tarumai volcano (Yokoyama, 2004). If we know the growth rates of lava domes, it is possible to find a relationship among the physical parameters of lava dome formation, such as viscosity of magmas, conduit dimension and driving pressure, by Hagen-Poiseuille Law which is conditioned for fluids to flow through a narrow space. In the present case, the growth rate $Q$ of lava dome is expressed as

$$
Q=\frac{\pi}{8} \frac{r^{4}}{\eta}\left(\frac{\Delta p}{l}-\rho g\right)
$$

where $r$ denotes the radius of the vent, $\Delta p$ driving pressure, $\Delta p / l$ pressure gradient, $l$ vertical length of the vent, $\rho$ density of lava, $g$ gravity acceleration and $\eta$ viscosity of lava. Among these factors, $\Delta p$ is liable to fluctuate due to degassing and crystallization in the magma. The viscosity $\eta$ determined by eq. (4.1) involves the effects of chemical components (mainly $\mathrm{SiO}_{2}$ and water), crystallization and temperature averaged for the period of dome formation, and their changes with time and space. Actually the temperature may be around $1000^{\circ} \mathrm{C}$. We may call such $\eta$ «macroscopic viscosity».

From eq. (4.1) we obtain

$$
\log Q=K-\log \eta
$$

where $K=\log \frac{\pi r^{4}}{8} \cdot\left(\frac{\Delta p}{l}-\rho g\right)$. 
The growth rates of the lava domes described in the previous chapter are tabulated in table I where those estimated by Newhall and Melson (1983) and Swanson et al. (1987) are additionally shown for reference. The growth rates are also plotted in logarithmic scale against $\mathrm{SiO}_{2} \%$ of lavas in fig. 1, where some of the growth rates (ordinate) have a rather high degree of uncertainty and their error ranges are calculated and indicated by the bars attached to the plots. The growth rates of the spines of Lamington and Pelée volcanoes are indicated by star symbols in fig. 1 for reference, and are significant-

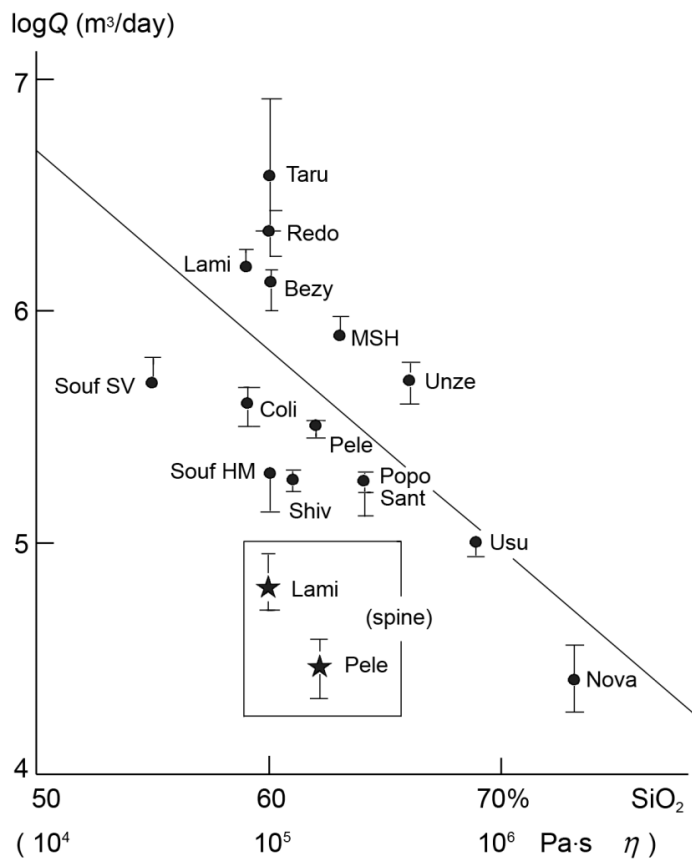

Fig. 1. Logarithm of $Q$ (growth rate of lava dome) versus $\mathrm{SiO}_{2} \%$. The two domes of spine-type (star symbols) are excepted from the least squares to determine the best fit line. The bars attached to the plots indicate the ranges of errors. $\eta$ along the abscissa denotes «macroscopic viscosity» with exponents in round figures. MSH - Mt. St. Helens; Souf SV Soufrière of St. Vincent; Souf HM - Soufrière Hills, Montserrat. ly smaller than those of their domes, respectively, because solidified or half-solidified spines may meet with higher resistance through conduits. Their formation processes do not obey Hagen-Poiseuille Law, and they are excepted from the following discussion.

As shown in fig. 1, the relationship between the $\log Q$ and the $\mathrm{SiO}_{2} \%$ is roughly linear though the plots are rather scattered, and classification of the plots into two groups, upper and lower, is not justified because of their inaccuracy. We may assume that $\log \eta$ can be replaced by $\mathrm{SiO}_{2} \%$ in eq. (4.2) and that $K$ does not vary with the volcano. Their relationship is determined by the least squares method as

$$
\log Q=11.04-0.087\left(\mathrm{SiO}_{2} \%\right)
$$

where the correlation coefficient is -0.68 . From eqs. ((4.2) and (4.4)), we obtain approximately

$$
\log \eta \fallingdotseq 0.087\left(\mathrm{SiO}_{2} \%\right) .
$$

Hence, we may label $10^{4.3}, 10^{5.2}$ and $10^{6.1} \mathrm{~Pa} \cdot \mathrm{s}$ in macroscopic viscosity for 50, 60 and 70 in $\mathrm{SiO}_{2} \%$, respectively on the abscissa of fig. 1. As the data increase in number, the parameters in eq. (4.4) should change necessarily.

At present, macroscopic viscosities calculated by eq. (4.5) are not directly comparable with the lava viscosities experimentally determined at $1000^{\circ} \mathrm{C}$. However, the former is usually lower than the latter as shown in table I. This is reasonable if we consider the effects of volatile material and crystallization in real lavas.

The growth rate $Q$ most strongly depends on $r$ and next on $\eta, \Delta p, l$ and $\rho$ in eq. (4.1). The linearity of the diagram $\left(\log Q \sim \mathrm{SiO}_{2} \%\right)$ suggests that $Q$ changes in logarithmic proportion to $\mathrm{SiO}_{2}$ percentage. Constant term $K$ in eq. (4.2) proves to be roughly common in logarithmic scale among various volcanoes. This is plausible when we consider that both toosmall-radius and too-large-radius conduits are not favorable for lava dome formation and that too shallow and too deep magma positions are not probable. Radii of the conduits feeding lava domes must be a few tens of meters in common. Driving pressure is liable to fluctuate as observed in some dome forming eruptions 
(Melnik and Sparks, 1999) and must have its limit because lava domes have a limit of their heights, a few hundred meters at maximum above the surface.

The result shown by eq. (4.5) is simple, but not a result of oversimplification. We should take into account that the growth rates may be correct in order of magnitude and the log-linear diagram is rather limited in resolvability. It means that growth rates in some eruptions may be affected by unsteadiness in driving pressure.

\section{Concluding remarks}

Firstly physical properties of magmas, temperature and viscosity, are examined in relation to lava dome formation. Growth rates of lava domes are expected to undergo the strongest effect by viscosity of magmas. Modes of dome formation are classified into two, squeeze- and spine-types, from the standpoint of the mechanism of magma movements. The majority of the lava domes mentioned in the present paper belongs to the squeeze-type. Squeezes of viscous and plastic magmas through conduits should satisfy Hagen-Poiseuille Law, by which growth rates are related to the viscosity of magmas. The viscosity involved in the law should be different from the normal viscosity of lavas, and is defined as macroscopic viscosity on the assumption that the temperature is around $1000^{\circ} \mathrm{C}$ during dome formation. Growth rates of the 15 lava domes formed in the 20th century are determined with reference to the published quantitative data. The relationship between the macroscopic viscosity and $\mathrm{SiO}_{2}$ content of lavas is statistically obtained through the agency of growth rates of the domes. Formation processes of lava domes of squeeze-type are strongly controlled by macroscopic viscosity of magma. On the other hand, the parameters in Hagen-Poiseuille Law, i.e. radius and length of the conduits, pressure gradient and density except viscosity, are found to be roughly common in logarithmic scale among various volcanoes.

If we know the $\mathrm{SiO}_{2}$ percentage of magma, we may have a rough idea of its macroscopic viscosity that controls the growth rate of the lava dome.

\section{Acknowledgements}

The author appreciates the assistance of Dr. T. L. Wright who critically read the first version of the manuscript and provided helpful suggestions for improvements. Dr. A. Goto kindly commented on rheology of magmas, to whom the author expresses deep thanks. This manuscript benefited very much indeed from the critical comments of an anonymous referee.

\section{REFERENCES}

BARDinTZEFF, J.M. and A. McBirney (1998): Volcanology (Jones Bartlett Pub., Sudbury, Mass.), pp. 268.

Bоoтh, B. and S. Self (1973): Rheological features of the 1971 Mount Etna lavas, Phil. Trans. R. Soc. Lond. A., 274, 99-106.

Calvache, V.M.L. and S.N. WiLliams (1997): Emplacement and petrological evolution of the andesitic dome of Galeras volcano, 1990-1992, J. Volcanol. Geotherm. Res., 77, 57-69.

DaAg, A.S., M.T. Dolan, E.P. Laguerta, G.P. Meeker, C.G. Newhall, J.S. Pallister and R.U. Solidum (1996): Growth of a postclimactic lava dome at Mount Pinatubo, July-October 1992, in Fire and Mud: Eruptions and Lahars of Mount Pinatubo, Philippines, edited by C.G. Newhall and R.S. PunOngbayan (Phil. Inst. Volcanol. Seismol. and Univ. Wash. Press), 647664.

DufFiEld, W.A., R.I. TILling and R. CANUL (1984): Geology of El Chichon volcano, Chiapas, México, J. Volcanol. Geotherm. Res., 20, 117-132.

Dvigalo, V.N. (1988): Growth of a dome in the crater of Shiveluch volcano in 1980-1981 from photogrammetry data, Volcanol. Seismol., 6, 307-315.

Fierstein, J., B.F. Houghton, C.J.N. Wilson and W. HilDRETH (1997): Complexities of plinian fall deposition at vent: an example from the 1912 Novarupta eruption (Alaska), J. Volcanol. Geotherm. Res., 76, 215-227.

Giordano, D. and D.B. Dingwell (2003): Viscosity of hydrous Etna basalt: implications for Plinian-style basaltic eruptions, Bull. Volcanol., 65, 8-14.

Giordano, D., C. Romano, P. Papale and D.B. Dingwell (2004): The viscosity of trachytes, and comparison with basalts, phonolites, and rhyolites, Chem. Geol., 213, 49-61

Global Volcanism Network (1996): Popocatépetl, Smithson. Inst. (GVN) Bull., 21 (8), 4.

GorshKov, G.S. (1959): Gigantic eruption of the Volcano Bezymianny, Bull. Volcanol., 20, 77-109.

Goto, A. (1997): An experimental study on the viscosity of some silicate melts, Ph.D. Thesis (Hokkaido University), pp. 106 (unpublished).

HiLDRETH, W. (1983): The compositionally zoned eruption of 1912 in the Valley of Ten Thousand Smokes, Katmai National Park, Alaska, J. Volcanol. Geotherm. Res., 18, $1-56$.

Huppert, H.E., J.B. SHEPHERD, H. SigurdSSON and R.S.J. 
SPARKS (1982): On lava dome growth, with application to the 1979 lava extrusion of the Soufrière of St. Vincent, J. Volcanol. Geotherm. Res., 14, 199-222.

KANI, K. and K. HosoKaWA (1936): On the viscosities of silicate rock-forming minerals and igneous rocks, Res. Rep. Electrotech. Lab., 391, 1-105 (in Japanese with English abstract).

KATILI, J.A. and A. Sudradjat (1984): Galunggung, the 1982-1983 Eruption (Volcanol. Surv. Indones.), pp. 102.

LacroiX, A. (1904): La Mt. Pelée et ses Eruptions (Masson et Cie, Editeurs, Paris), 2 vols., pp. 662.

MACIAS, J.L., M.F. SHERIDAN and J.M. EsPINDOLA (1997): Reappraisal of the 1982 eruptions of El Chichon volcano, Chiapas, México: new data from proximal deposits, Bull. Volcanol., 58, 459-471.

Matthews, S.J., M.C. Gardeweg and R.S.J. Sparks (1997): The 1984 to 1996 cyclic activity of Lascar Volcano, Northern Chile: cycles of dome growth, dome subsidence, degassing and explosive eruptions, Bull. Volcanol., 59, 72-82.

MELnIK, O. and R.S.J. SpARKS (1999): Nonlinear dynamics of lava dome extrusion, Nature, 402, 37-41.

Melnik, O. and R.S.J. SPARKS (2002): Dynamics of magma ascent and lava extrusion at Soufrière Hills Volcano, Montserrat, in The Eruption of Soufrière Hills Volcano, Montserrat from 1995 to 1999 , edited by T.H. DRUITT and B.P. KokelaAr, Geol. Soc. Mem., 21, 153-171.

Miller, T.P. (1994): Dome growth and destruction during the 1989-1990 eruption of Redoubt Volcano, J. Volcanol. Geotherm. Res., 62, 197-212.

Moore, J.G. and W.C. AlbeE (1981): Topographic and structural change, March-July 1980 - Photogrammetric data, in The 1980 Eruption of Mt. St. Helens, Washington, edited by P.W. LIPMAN and D.R. MullinEAuX, U.S. Geol. Surv. Prof. Pap., 1250, 123-134.

Moore, J.G., P.W. Lipman, D.A. Swanson and T.R. AlPha (1981): Growth of lava domes in the crater, June 1980January 1981, in The 1980 Eruption of Mt. St. Helens, Washington, edited by P.W. LIPMAN and D.R. MULLINEAUX, U.S. Geol. Surv. Prof. Pap., 1250, 541-547.

Murase, T., A. Mcbirney and G.M. William (1985): Viscosity of the dome of Mt. St. Helens, J. Volcanol. Geotherm. Res., 24, 193-204.

Murphy, M.D., R.S.J. Sparks, J. Barclay, M.R. CARroll, A.M. Lejeune, T.S. Brewer, R. Macdonald, S. BLACK and S. Young (1998): The role of magma mixing in triggering the current eruption at the Soufrière Hills volcano, Montserrat, West Indies, Geophys. Res. Lett., 25, 3433-3436.

NAKADA, S. (1996): The eruption of Unzen-Fugendake Effusion rates, mode of dome formation, and relation with lava composition, Chikyu Monthly, Extra No. 15, 64-69 (in Japanese).

NaKada, S., H. Shimizu and K. Ohta (1999): Overview of the 1990-1995 eruption at Unzen Volcano, J. Volcanol. Geotherm. Res., 89, 1-22.

NAVARro-OchOA, C. (2002): Movement and emplacement of lava flows at Volcan de Colima, México: November 1998-February 1999, in Abstracts of the 8th International Meeting of Colima Volcano, p. 103

Newhall, C.G. and W.G. Melson (1983): Explosive activity associated with the growth of volcanic domes, $J$. Volcanol. Geotherm. Res., 17, 111-131.
Nichols, R.L. (1939): Viscosity of lava, J. Geology, 47, 290-302.

OinOUYE, Y. (1909): A report of the 1909 eruption of Tarumai volcano, Rep. Imp. Earthq. Inv. Com. No. 64, 1-23 (in Japanese).

PAterson, W.S.B. (1994): The Physics of Glaciers (Reed Educa. Profes. Publ. Ltd.), pp. 480.

Robin, C. and C. Boudal (1987): A gigantic Bezymiannytype event at the beginning of modern volcan Popocatépetl, J. Volcanol. Geotherm. Res., 31, 115-130.

Romano, C., D. Giordano, P. Papale, V. Mincione, D.B. Dingwell and M. Rosi (2003): The dry and hydrous viscosities of alkaline melts from Vesuvius and Phlegraean Fields, Chem. Geol., 202, 23-38.

Rose, W.I. JR. (1972) Notes on the 1932 eruption of Santa Maria volcano, Guatemala, Bull. Volcanol., 36, 29-45.

Rose, W.I. JR. (1973): Pattern and mechanism of volcanic activity at the Santiaguito volcanic dome, Guatemala, Bull. Volcanol., 37, 73-94.

Shepherd, J.B., W.P. Aspinall, K.C. Rowley, J. Pereira, H. SigurdSSON, R.S. Fiske and J.F. Tomblin (1979): The eruption of Soufrière volcano, St. Vincent AprilJune 1979, Nature, 282, 24-28.

SPARKS, R.S.J. (1977): Causes and consequences of pressurisation in lava dome eruptions, Earth Planet. Sci, Lett., 150, 177-189.

Sparks, R.S.J., S.R. Young, J. Barclay, E.S. Calder, P. Cole, B. Darroux, M.A. Davies, T.H. Druitt, C. Harford, R. Herd, M. James, A.M. LeJeune, S. Loughlin, G. Norton, G. Skerrit, M.V. Stasiuk, N.S. Stevens, J. Toothill, G. WAdGe and R. WAtTs (1998): Magma production and growth of the lava dome of the Soufrière Hills volcano, Montserrat, West Indies: November 1995 to December 1997, Geophys. Res. Lett., 25, 3421-3424.

STOIBER, R.E. and W.I. Rose JR.(1969): Recent volcanic and fumarolic activity at Santiaguito volcano, Guatemala, Bull. Volcanol., 33, 475-502.

Subandriyo, M., Ch. Supriyati, D.A. Suharno and SRI SubANDINI (1992): The 1992 Merapi eruption viewed from seismic and deformation data and the lava doming process, in Rep. Indonesian Ass. Geol, 21st Ann. Conv. 1992, 1-19.

Swanson, D.A., D. Dzurisin, R.T. Holcomb, E.Y. IwatSubo, W.W. Chadwick JR., T.J. CASAdEvall, J.W. EWERT and C.C. HeliKeR (1987): Growth of the lava dome at St. Helens, Washington, (USA), 1981-1983, in The Emplacement of Silicic Domes and Lava Flows, edited by J.H. Fink, Geol. Soc. Am., Special Pap., 212, $1-16$.

TAYLOR, G.A. (1958): The 1951 eruption of Mt. Lamington, Papua, Comm. Australia Bur. Min. Res. Geol. Geophys. Bull., 38, pp. 117.

Watts, R.B., R.A. Herd, R.S.J. Sparks and S.R. Young (2002): Growth patterns and emplacement of the andesite lava dome at Soufrière Hills Volcano, Montserrat, in The Eruption of Soufrière Hills Volcano, Montserrat from 1995 to 1999 , edited by T.H. DRUITT and B.P. KoKelaAr, Geol. Soc. Mem., 21, 115-152.

YANAGI, T., S. NAKAdA and S. MAEDA (1992): Temporal variation in chemical composition of the lava extruded from the Jigokuato crater, Unzen volcano, in Unzen Volcano the 1990-1992 Eruption, edited by T. YANAGI, 
H. OKADA and K. OHTA (The Nishinippon \& Kyushu Univ. Press), 56-66.

YOKOYAMA, I. (2004): Formation processes of the 1909 Tarumai dome and the 1944 Usu dome in Hokkaido, Japan, Ann. Geophysics, 47 (6), 1811-1825.

Yokoyama, I. and M. SEINo (2000): Geophysical compari- son of the three eruptions in the 20th century of Usu volcano, Japan, Earth Planets Space, 52, 73-89.

(received February 10, 2005; accepted August 2, 2005) 